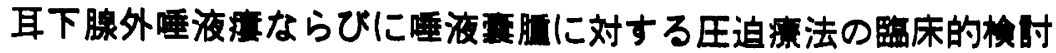

\author{
田代英雄・中村誠司*·策原正徳* \\ 村上英輔・岡 增一郎*

\section{Clinical study of the pressure dressing therapy for parotid salivary fistulas and sialoceles} \\ Hideo Tashiro - Seiji Nakamura* - Masanori Shinohara* \\ Eisuke Murakami - Masuichiro OKa*
}

\begin{abstract}
Although persistent parotid salivary fistulas and sialoceles are relatively rare surgical entities, patients with these diseases are considerably suffered from facial deformity or massive outpouring of saliva in general. Many therapeutic methods ranging from conservative treatment to more radical surgical intervention have been used for treating these diseases. In this paper, the therapeutic effect of pressure dressing, one of these measures, was examined in 7 cases of parotid salivary fistula or sialocele. Pressure dressing was performed using a sponge and elastic mesh or elastic bandage. This simple procedure resulted in closure of fistula or disappearance of sialocele in all cases. In the case of lacerated parotid duct, however, the parotid function was degenerated, suggesting that the gland underwent atrophy.

It seemed that pressure dressing is suitable for such cases as having lacerated parotid gland or those in whom the parotid function is impossible to maintain. In addition, this more easy and safe pressure dressing is considered to be a measure of first choice for intending functional cessation of the parotid gland, although other treatments including removal of the auriculotemporal nerve or radiation are also applicable.
\end{abstract}

Key words: salivary fistula, parotid gland disease, pressure dressing

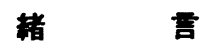

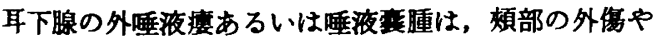
化晨性资の切開後の，まれではあるが厄介な後遗症の一 つである. すなわち、このようなるのが起こると患者に とって著しい苦痛となるのに, これらの治療は容易でな

九州大学莯学部第 1 口腔外科学教室

（主任：田代英雄教授）

* 九州大学齿学部第 2 口腔外科学教室

（主任：岡 增一郎教授）

First Department of Oral Surgery, Faculty of Dentistry, Kyushu University (Chief: Prof. Hideo Tashiro)

* Second Department of Oral Surgery, Faculty of Dentistry, Kyushu University (Chief: Prof. Masuichiro Oka)

受付日：昭和59年 2 月 20 日
いことが多い，そのため，これまでいろいろな治療法が 工夫され，それらの経験が報告されている ${ }^{1 \sim 10)}$ ．著者ら は，このよらなものに対して最も簡単な殴迫察法を応用 することが多いが，いずれも瘦からの唾液の流出や睡夜 の眝留を停止させることには成功している。これらの治 療経験に基づき, 本療法の効果, 長所短所について検討 を行ったので報告する。.

\section{症例と治療方法}

症例は1972年より1982年までの11年間化九州大学曾学 部附属病院口腔外科を受診し，压迫療法によって治㞠し

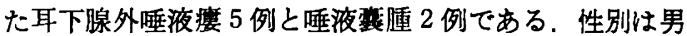
性 5 例, 女性 2 例であり, 発症時年龄は10嵗から50歳ま でであった（表1）.

1 例は耳下腺部の化膿性炎症の切開後に発症したもの であるが，他の 6 例はいずれる事故による外傷によって 生したものであった，受傷部位，瘘あるいは衰連形成部 
交 1 检染症侧

\begin{tabular}{|c|c|c|c|c|c|c|}
\hline 症例 & 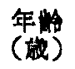 & 性别 & 皕 類 & 原 因 & \multicolumn{2}{|c|}{ 强伤部位 } \\
\hline 1 & 10 & 女 & 外啗液埕 & 资症 & 㙞婂 & 本部 \\
\hline 2 & 18 & 男 & 外唯液贯 & 外场 & 滕代 & 本激 \\
\hline 3 & 23 & 女 & 外嘅液港 & 外侮 & 管 & 部 \\
\hline 4 & 50 & 男 & 外咟液瘄 & 外俈 & 不 & 明 \\
\hline 5 & 52 & 男 & 外哑液清 & 外侮 & 管 & 部 \\
\hline 6 & 18 & 男 & 㗺液雷腫 & 外保 & 管 & 部 \\
\hline 7 & 39 & 男 & 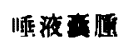 & 外伤 & 管 & 部 \\
\hline
\end{tabular}

位あるいはソンデによる探索所見などより掦儌部位を

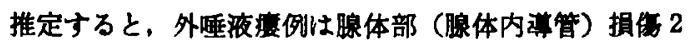
例，管部（腺体外管）損伤 2 例で，1 例はいずれとも

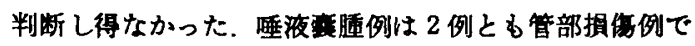

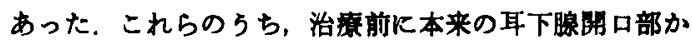

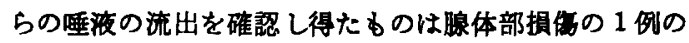
みであった（写真1〜3）.

これらの应例に対して受診後ただちに压迫度法を行っ たが，受傷後または切開後治療開始までの期間は 7 日か 536日までであった，管部損伤例に圧迫療法が適用され たのは，いずれる煩部の損伤の程度あるいは洀痕形成の 程度が高度で，管の修復による再建や内唾液浱への転換 が容易には成功し難いと考えられたためであった。

王迫は，瘦孔部または晎腫形成部の上飞娍菌ガーセを おき，その上に耳下腺部にす圧迫が加わるよらにスポン シジロックを重ねて，頭部を含め弾性網包带あるいは弾 性包帯で巻く方法によって行った（写禹 4，5）.

\section{治 療 成 樍}

\section{1. 治瘄効果と治㽷期间}

全症例とる本療法によって，それぞれ瘦孔の閉鎖，衰 腫の消失をみた。

王迫療法開始後，瘦孔からの唾液流出の停止あるいは 熟腫の消失までの期間は，腺体部損傷例では 1 日から 3 日，管部損傷例では 4 日から11日であった。 ただしこの 期間は毎日正確に患者を診察したわけではなく，またそ のたびに压迫をやめて長時間钼察したわけでるなく，さ らにこれらの時点より引続き 3 日から11日間追加圧迫を 行っているので正確なるのとはいい難く，おおよその印 象によるわのである、管部損傍例の方がより長期間の压 迫を行った（表 2).

\section{2. 治虑後の機能}

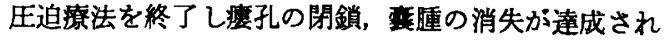
たと判断された後の本来の開口部からの唾液流出は, 腺 体部損侮例では治療前に流出が確認できなかった 1 例も

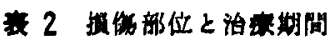

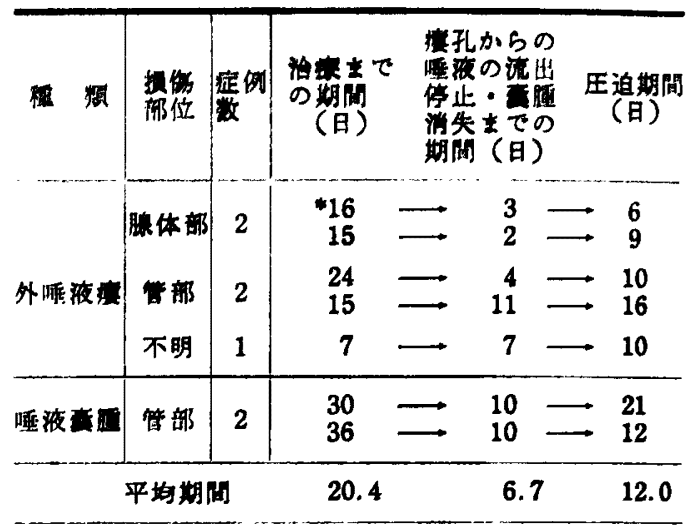

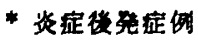

表 3 本来の開口部からの厓洨の施出

\begin{tabular}{|c|c|c|c|c|}
\hline \multirow{2}{*}{ 種 類 } & \multirow{2}{*}{ 层伤部位 } & \multirow{2}{*}{ 症例数 } & \multicolumn{2}{|c|}{ 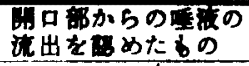 } \\
\hline & & & 治 事前 & 治来後 \\
\hline \multirow{3}{*}{ 外喠液激 } & 腺体部 & 2 & (1 $\stackrel{1}{1}$ 明不明) & 2 \\
\hline & & 2 & 0 & 0 \\
\hline & 不 明 & 1 & （不明） & 1 \\
\hline 鲐液勧腫 & 管 部 & 2 & 0 & 0 \\
\hline
\end{tabular}

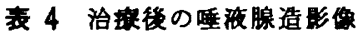

\begin{tabular}{|c|c|c|c|c|}
\hline 症例 & 種類 & $\begin{array}{l}\text { 損俳 } \\
\text { 部位 }\end{array}$ & 造䇣までの & 唾液腺造影像 \\
\hline 1 & 外唾液症 & 媳体部 & 3 年 8 か月 & 完全描出. 正常像 \\
\hline 2 & 外喠液痃 & 媳体部 & 3 年 2 か月 & 完全描出. 正常像 \\
\hline 3 & 外唾液瘖 & 管部 & 2 か月 & $\begin{array}{l}\text { 耳下腺管の一部描出 } \\
\text { 腺体描出不能 }\end{array}$ \\
\hline 5 & 外唾液竞 & 管部 & 6 年 8 か月 & $\begin{array}{l}\text { 耳下腺管の一部描出 } \\
\text { 腺体描出不能 }\end{array}$ \\
\hline
\end{tabular}

含めて 2 例とす認められた。しかしながら，管部損筮例

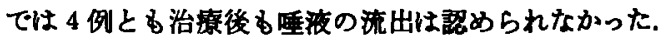
腺体部、管部いずれの損䅞と判断し得なかった 1 例では 流出は認められた（表了）。

4 例飞ついて治㞠後に棰夜腺造影を行らことができ た. その結果，腺体部損伤例では 2 例とすはぼ完全飞腺 体が描出されたが，管部損侮例の 2 例はいずれも管部の 口腔側の一部のみが描出され，腺体は描出されなかった (表 4 ，写页 6).

管部損傷例の5ち 1 例では，治療後飞 ${ }^{99 \mathrm{~m} T \mathrm{~T} \text {-perte- }}$ chnetate による RI シンチクララフィーを行った．本例 は唾液腺造影でも患側の腺体は描出されなかったか，患 


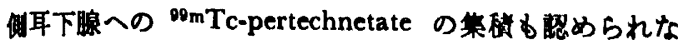

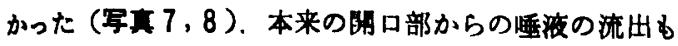
認められず，本例の患㑡の耳下腺機能は篦絶したものと 考えられた。

\section{考察}

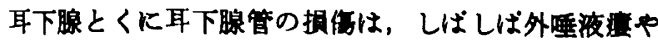

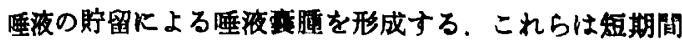
での自然治思は期特できず，また治患が容易でないこと b多いので，その予助や治暴法について多くの方法が報 告されている ${ }^{1 \sim 10)}$. 当教室においても，断裂した耳下腺 管の細いカテーテルを轴とする吻合 ${ }^{11}$ ，血管移植による

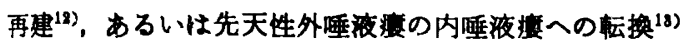
を報告しており、これらの方法は多くの人たちも推奖し ている2,8,6,14 23) よ5に耳下腺の機能を保存することを 企図した治港法でありすぐれたるのといえよう，しかし ながら，最る逼遇することが多い外的後日数を経て気付

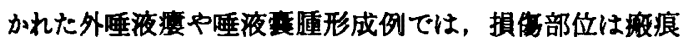
組織の中に埋すれ，再び創を開いてみても断端をみつけ ることも，再建することも，あるいは内隀液瘄に転換す ることも容易ではないと考えられる场合が多い，耳下腺 管に陪接して走行することが多い顔面神経を見出すのは 困難であるため，顔面神䅅を損伤する危険珄すあり，ま た耳下腺管の管腔はきわめて細いので，再建してる痕痕 収樎に抗してその流通性を長く維持するのは困難なこと が多いと思われる。

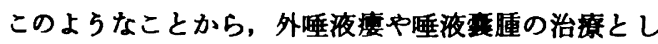
てはしばしば再建を諦め,むしろ耳下腺機能の廃絶を企 図した耳下腺分沙神経の切断1,10,25 27)，耳下腺管の結热

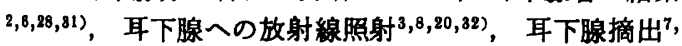
8,38,84) などが行われている. 著者らは，管部損侮例でこ のような再建が不可能と思われる症例にはまず圧迫療法 を行らこととしている．また腺体部損伤例では，陳旧例

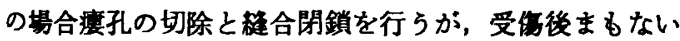
場合には同様に王迫療法によって治療している. 当初こ のよらな治㞠法にそれほどの期待をすたず，いずれ上 記のよ5な手術あるいは放射線照射による積極的な耳下 腺の機能廃絶処直を必要とするであろらと考えていた が，いずれる圧迫のみによって丧孔からの唾液の流出は 停止し，菲腫も消失した。

王迫療法はきわめて简単な治療法であり，実際には普 週的に行われているすのであるかるしれないが，王迫㞠 法についての記载は少ない,34〜39)，臣迫を行った報告の 多くは，腺体部損傷例についてのるのである. Epker $5^{6)}$, 富田 ${ }^{35)}$, 今野 ${ }^{36)}$ は, 腺体部の損侮は創の確実な 閉鎖のあとに局所圧迫を加えれば治等すると述へてい る. 原科 ${ }^{34)}$ は腺体部損傷後の唾液落腫が穿刺吸引と圧 迫を併用して，6週間で消失したと報告している，また

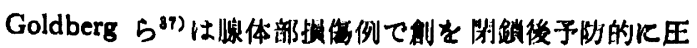

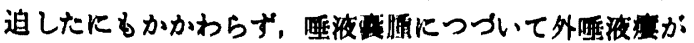

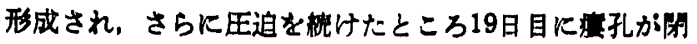

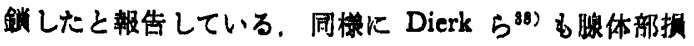

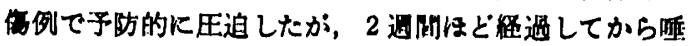

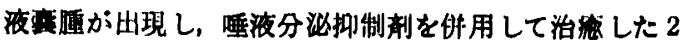

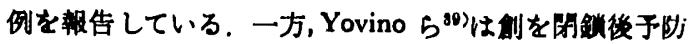
的に圧迫したが，管部にも损借があったため 3 過间後に

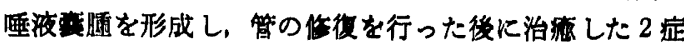

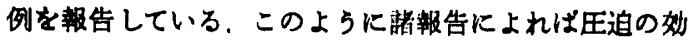
果は礁実とはいえないか，著者らの経涘では多くは管部 損伤例であったにむかかからず，すべて目的を果たすこ とができた，著者らが行った圧迫筫法の期間は6日から 21日で，平均は12.0日であった，これらの経検よりする と，王迫期間の目安は，王迫を除いてみて㾂孔からの唾 液の流出停止あるいは变隀の消失が認められてから5 日 間程度追加圧迫を行えば再発は起こらないようである。

圧迫療法の治恚機転については今まで報告されていな いが，導管の結禁㳟法については報告がある

Morestin ${ }^{28)}$ は外伤により生じた外厘液璂の多くは自然治

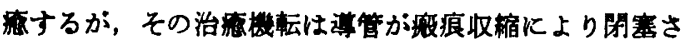
れ腺組織の萎樎が起こることによると推測し，耳下眿管 損倠による外唾液展は耳下腺管の結㷊を行 5 と良好な結 果が得られると報告している，その後多くの人たちが耳 下腺管の結禁を行って目的を埖したことを報告している 2,6,28 31). Baron ${ }^{40)}$ は損傷した耳下眿管を結禁すること によって外唾液瘖が治寉した症例において，5年後に患 側耳下腺を摘出し組織学的検索を行ったところ，腺組耭 は脂肪および線維性組織におきかわっていたと報告して いる.

今回報告した圧迫例においても，治療後の状態で，管 部損傷例では本来の開口部からの涶液の流出が垫められ ず，造影所見です管は閉鎖しており，また1例ながら ${ }^{99} \mathrm{~m}$ Tc-pertechnetate による RI シンチグラフィーを行 った例では，耳下眿のその集積像は認められなかった。 これらはいずれも，腺体全部の機能廃絶を示すむのであ る.腺体部損侮例においてす，圧迫後は部分的には腺組 織の萎摍が起こっているものと考えられる.

一側の耳下腺機能の廃絶はさほど障害とならず，患者 にとっても通常の状態では自覚的には何ら痛痒を感じな い程度のすのである。しかしながら，機能廃絶を前提と した治療法は理想的なすのとはいい難く、できれば手術 的に再建をはかるべきるのであろら.

先にも述べたよらに，このような手術的再建が容易で ないために，次善の策として機能廃絶を目的に種々の手 術や放射線照射が行われているわけであるが，著者らは このよらな目的や腺体部損傷例ではこれらの面倒な処着 は行わなくても，簡単な圧迫ですむものがかなり多いの ではないる考えている。すっとも少数例の経験からの 
印象であって，今後棪时を五ねたい。<smiles>[14CH3]</smiles>

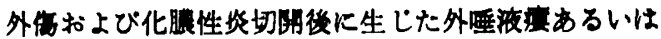

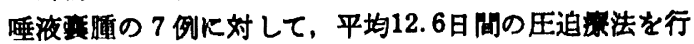

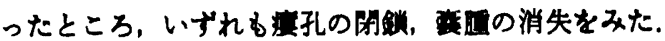

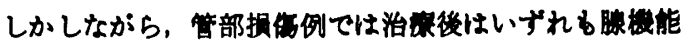
が全く婼絶しているむのと考えられた。 このよろなこと

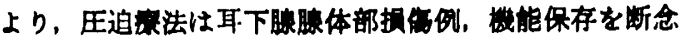
した耳下管部損仿例では，分泌神経の切断中耳下腺摘出

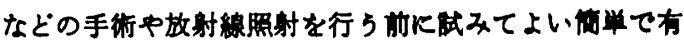
奻な治茧法であると考えられた。

本諭文の要旨は，1983年第37回日本口腔科学会総会 （大报）に拈いて啹告した。

\section{引用 女 献}

1) Dieulafe, L.: Salivary fistulx. Ann Otol Rhinol Laryngol 27: 1372-1385 1918.

2) Sparkman, R.S.: Laceration of parotid duct; further experiences. Ann Surg 131: 743-754 1950.

3）北村 武，佐久間武司：耳下腺㾯について。日 医事新報 1487: 3581-3584 1952.

4) Joffe, N.: Some sialographic findings in traumatic lesions of the parotid duct and gland. Am J Roentgenol 100: 656-663 1967.

5) Thoma, K.: Oral Surgery II. 5 th Ed, Mosby Co, St Louis, 1969, p 709-710.

6) Epker, B.N. and Burnette, J.C.: Trauma to the parotid gland and duct: primary treatment and management of complications. J Oral Surg 28: 657-670 1970.

7) Kitamura, T. and Togawa, K.: Surgery of Stensen's duct. Arch Otolaryngol 193: 1891931971.

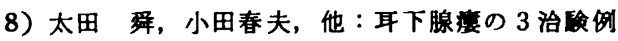
とその処圈に関する㭘討， 口科誌 21：102910401972.

9) Archer, W.H.: Oral and Maxillofacial Surgery I. 5 th Ed, Saunders Co, Philadelphia, 1975, p 943-944.

10) Chadwick, S.J. and Templer, J.W.: Parotid fistula; current management. South Med J 72: 922-926 1979.

11）田代英雄：影・顔面外甥患者の取报い一一初期

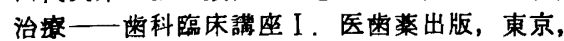
1981, 169-176頁.

12）藤野博，佐々木元蜸，他：喠液腺管形成手術 に関する研究(会)。口科誌 8：356 1959.

13）山畸 裕, 渡辺哲章, 他：先天性外耳下腺瘦の

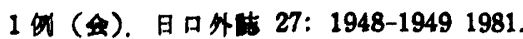

14) Goodall, R.E. and Flanders, S.E.: Succesuful primary repair of lacerated Stenwon's duct. Surg 21: 865-869 1946.

15) Sparkman, R.S.: Primary repair of severed parotid duct. Ann Surg 129: 652-661 1949.

16) Bornstein, L.A. and Simon, B.E.: Succesful primary repair of severed parotid duct. Plast Reconstr Surg 6: 217-227 1950.

17) Boyer, H.E.: Surgical repair of a severed parotid duct. report of case. J Oral Surg 18: 248-251 1960.

18) Weinstein, 1.: Anastomosis of a severed parotid duct: report of case. J Oral Surg 20: 156-158 1962.

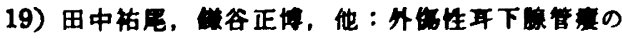

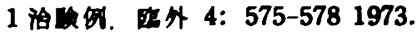

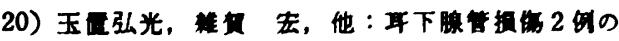

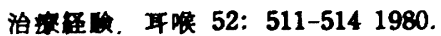

21) Stevenson, J.H.: Parotid duct transection associated with facial trauma: experience with 10 cases. Br J Plast Surg 36: 81-82 1983.

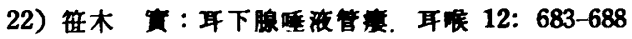
1939.

23）名合英明，宫沢正站，他：可耳を伴5先天性耳

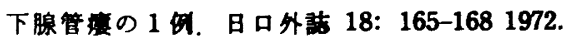

24）曾田忠雄, 別部尚司, 他：先天性扰よひ外伤性

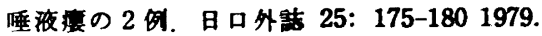

25) Morgan, W. R.: Parotid duct ligation and tympanic neurectomy. Arch Otolaryngol 98: 179-182 1973.

26) Mandour, M.A., El-Sheikh, M.M., et al.: Tympanic neurectomy for parotid fistula. Arch Otolaryngol 102: 327-329 1976.

27) Davis, W.E., Holt, G.R., et al.: Parotid fistula and tympanic neurectomy. Am J Surg 133: 587-589 1977.

28) Morestin, H.: Contribution a l'etude du traitement des fistules salivaires consecutives aux blessures de guerre. Bull Soc Chir Par 43: 845-855 1917. (quoted by Sparkman, R.S. 1950)

29) Ivy, R.H.: Collective review. war injuries of the face and jaws. Int Abstr Surg 27: 101117 1918. (quoted by Sparkman, R.S. 1949)

30) Landry, R.M.: Traumatic pseudocyst formation of the parotid duct. a safer method of obliteration. AMA Arch Surg 76: 97-99 1958.

31) Baron, H.C.: Surgical correction of salivary fistula. report of five cases. Ann Surg 153: 545-554 1961.

32) Reeves, R.J.: Roentgen therapy of bilateral parotid fistula. Am J Roentgenol 43: 425 1946.

33) Lichtenstein, J.L. and Kopp, W.K.: Closure of a parotid salivary fistula. J Oral Surg 23: 
497-498 1965.

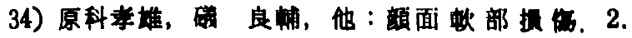

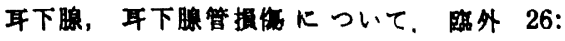
1407-1409 1971.

35）中村平藏監作：最新口腔外科学。第 2 版，医相 苏出版，東京，1974，823-824頁.

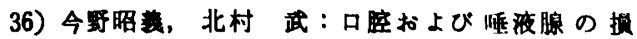
佮. 耳晚 48: 805-814 1976.

37) Goldberg, M.H., Marco, W., et al.: Parotid fistula: a complication of mandibular osteo- tomy. J Oral Surg 31: 207-208 1973.

38) Dierks, E.J. and Granite, E.L.: Parotid sialocele and fistula after mandibular osteotomy. J Oral Surg 35: 299-300 1977.

39) Yovino, S. and Stratigos, G.T.: Traumatic pseudocyst of the parotid gland. J Oral Surg 32: 121-124 1974.

40) Baron, H.C. and Ober, W.B.: Parotid gland atrophy. observation after ligation of Stenson's duct. Arch Surg 85: 1042-1044 1962. 


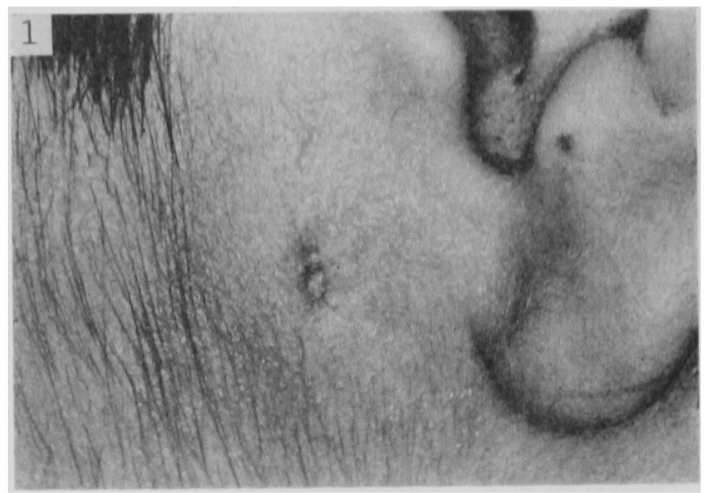

军重 1 症例 1 ：腺体部切開後の外隀液㿋

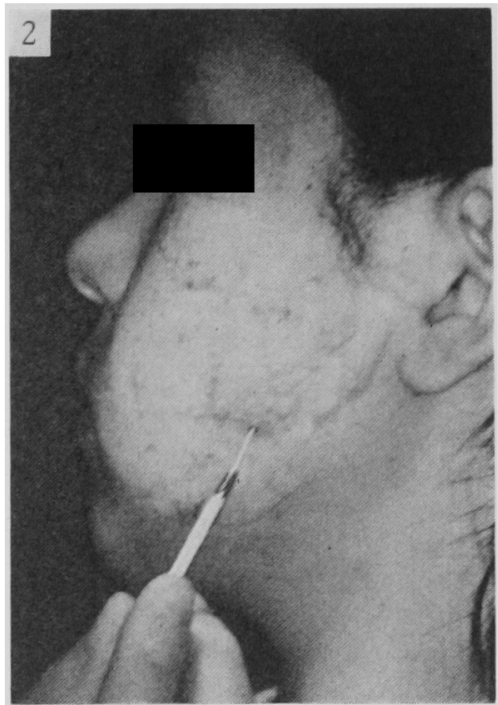

写真 2 症例 3：管部損伤後の外唾液瘦

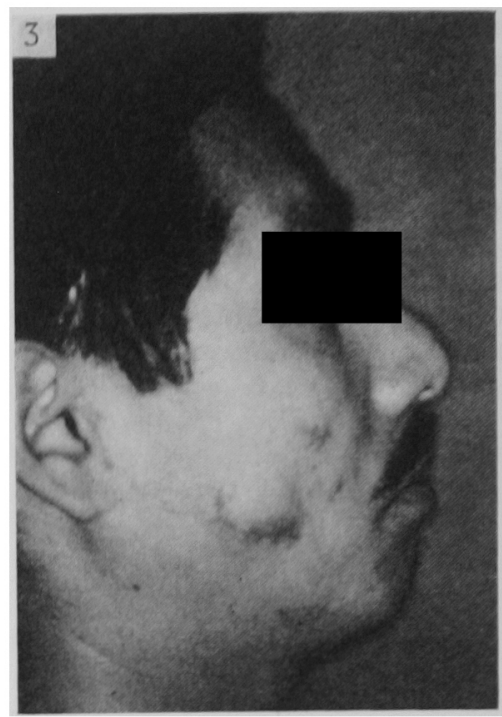

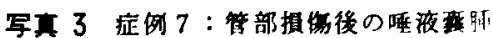

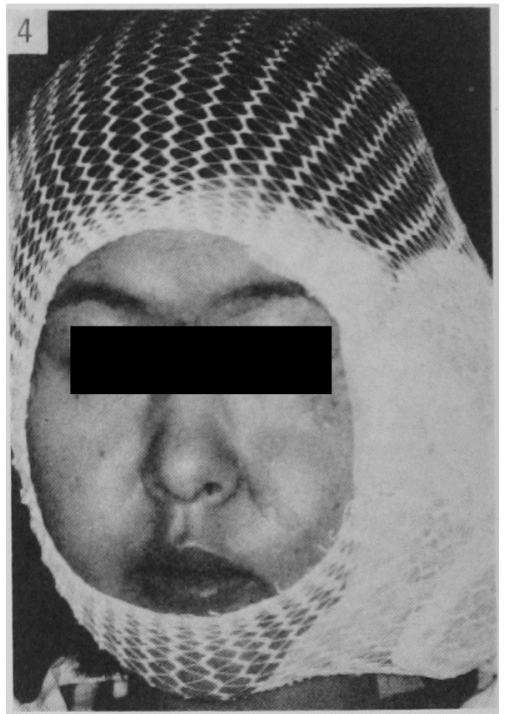

写本 4 症例 3 : スボンジと弾性網包带 に上る区迫治療 


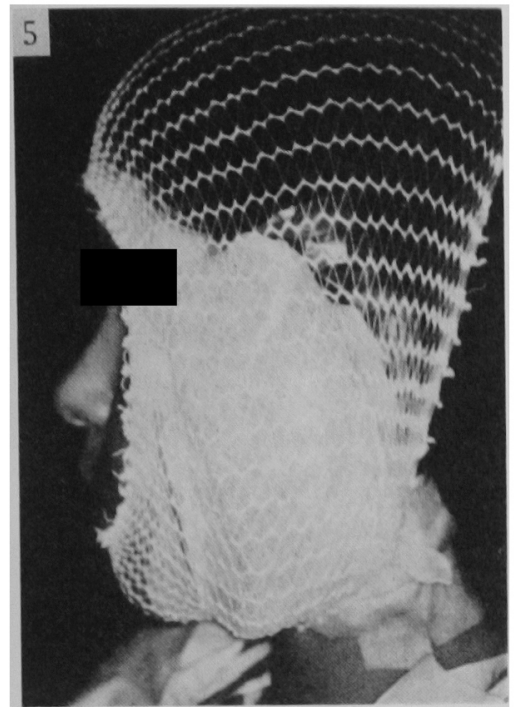

写高 5 同一症例の側面

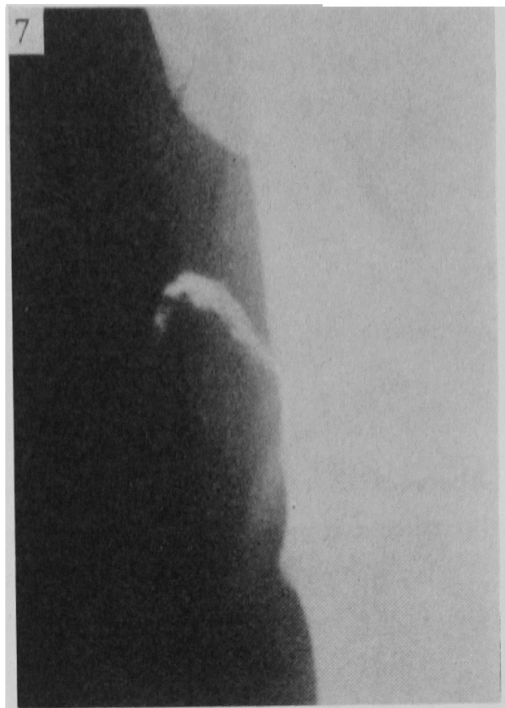

写交 7 同一症例の治蛙後の正面からの浭液 腺造影像

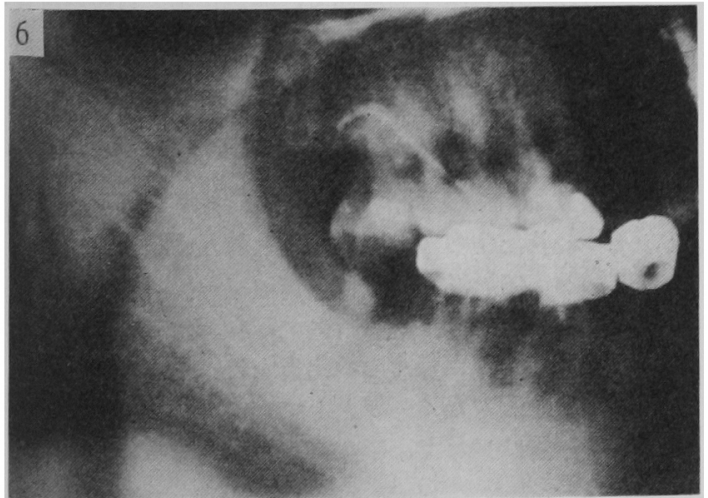

写声 6 症例 5 ：治療後の唾液腺造影像. 耳下腺管の一 部の久描出され，腺体の摘出は認められない

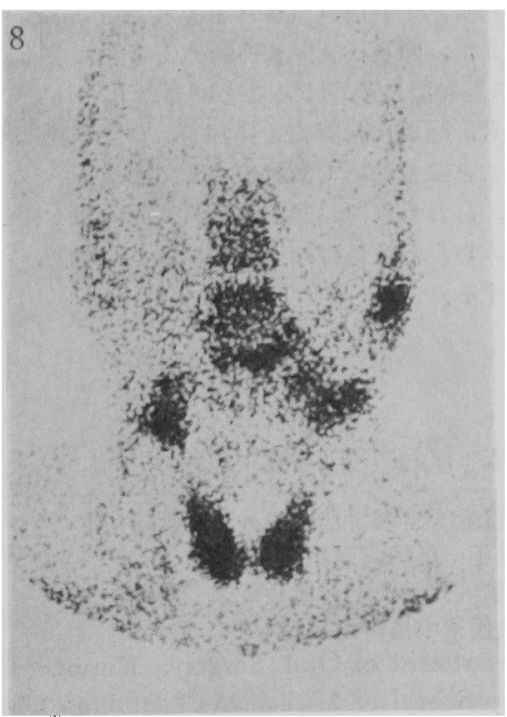

写真 8 同一症例の治潦後の RI シンチグラフィー 像，右側耳下腺部への ${ }^{89 \mathrm{~m} T c-p e r t e c h n e t a t e}$ の集楀は認められない 